\title{
Balancing Work and Life: Challenge Ahead
}

\author{
${ }^{1}$ Dr. Pagudala Suchitra \\ ${ }^{1}$ Professor and Principal,Dr.K.V.Subba Reddy Institute of MCA, NH-7, Dupadu(RS) Kurnool-518218
}

\section{Introduction}

Over the recent years, significant changes have taken place in the social, economic, technological and political environment of the Indian business. The government's policy of economic liberalization and stimulating globalization of business have brought many opportunities and threats for the modern organizations. ${ }^{2}$ (Chhabra, T.N,2000) The Human Resource (HR) professional's can't ignore such changes, rather they have to design and execute innovative mechanisms of developing skills and competencies of human resources to prepare them to accept the emerging challenges including :

- Changing international environment

- Changing needs and expectations of customers

- Changing profile of work force

- Advancement of technology

- Revolution in information technology

- Need for building up 'knowledge Capital'

- Economic and Industrial Policy changes

The above trends will have a tremendous impact on the tasks of HR Managers who will have to act as 'Change Agents' or 'Change Facilitators'. They will have to build a 'Learning Organizations' having the capacity and capability to learn from experimentation, past experiences and the experiences of others and transfer the learning to all HR for greater organizational effectiveness.

\section{Areas that work-life imbalance show their effects are:}

$>$ Growth and profit. Accelerated on and off-the-job stresses and expectations are adversely affecting top and bottom-line growth, unnecessarily driving down productivity. A well-implemented work-life strategy greatly reduces both the real and perceived overwork and out-of-balance pressures that hamper productivity, producing a dramatic positive return on investment.

$>$ Full Engagement and customer service. A workforce that is out of balance, unnecessarily stressed, or disgruntled greatly reduces full engagement with external and internal customers. Conversely, commitment to the organization's objectives and clients' needs rises in direct proportion to the perception that the organization is committed to both the work and life success of each individual.

$>$ Competitive advantage for talent. Demanding baby boomers--and even more, the smaller pool of younger workers--have increased their expectations of a positive work-life culture. Employees expect their employers to recognize that in addition to having a job, they have a life. This is reflected by the fact that work-life balance issues with the boss or the company are the number-one reason that individuals quit their jobs.

$>$ Health-care cost solution. The rising organizational cost of health care is driving senior management to become more proactive about employee health. Senior managers view engaging employees in improving their own lifestyle behaviors and creating a healthier workplace as key components to the solution.

Because of the business and personal links between these critical issues, executives now recognize that organizational objectives and individual work-life objectives are not "either/or" choices. It is the job of the senior management team and specifically HR to make this happen in ways that are consistent with the organization's business and customer-service objectives. Unfortunately, even as the demand for work-life solutions has skyrocketed, many work-life efforts have fallen short of their promise and potential to deliver the desired results for the individual and the organization. Positive new trends in the field, however, show that results can live up to expectations.

The demand for work-life-balance solutions by employees and managers is expanding at an unprecedented rate. As a result, work-life balance is an increasingly hot topic in boardrooms and government halls today. Over the coming decade it will be one of the most important issues that executives and human resource professionals will be expected to manage. Many people think of work-life balance only in the framework of what the company does for the individual. However, work-life balance is a two prong approach. The other prong of work-life balance, which many individuals overlook, relates to what individuals do for themselves. According to Jim Bird, CEO of Worklifebalance.com, "Work-life balance is a meaningful 
achievement and enjoyment in everyday life." The primary way companies can help facilitate work-life balance for their employee is through work-life programs and training. Achievement and enjoyment at work is a critical part of anyone's work-life balance. Furthermore, achievement and enjoyment in the other three quadrants of one's life (e.g. family, friends and self) is critical as well.

Managements' focus in the sphere of work organization and work force governance is changing from one of managing worker to that of managing work. The organizations today realize that HR is the greatest asset and are adopting policies like Competency Mapping and Building, Job Rotation, Empowerment, Work life Balance etc which promote the overall development of the workers. Greater stress is also being given in the field of labor welfare and social security with increased post-retirement benefits like health Insurance, Provident Fund, Pension etc.

Many organizations feel that helping the employees to balance competing work and non work demands is not their responsibility. It was the employee's choice to have a family, so balancing the increasing demands' is his problem and not that of the organization. Such organizations also should note that they are 'in the businesses of increasing share holder value and serving customers and not helping employees cope up with stress. In other organizations, helping employees balance their life is a HR issue and various initiatives are taken to create this balance. It has been found that uptake and reduction in work life conflict is closely related to organizational environment/work place culture ${ }^{7}$ (Hudson 2005).

While the concept of work - family culture has been operationalised in different ways, some measures of supportiveness within the organization is a consistent factor with superior managerial support being one aspect of it. ${ }^{1}$ (Bond,2004)

\section{Reasons for work life imbalance}

The past two decades has seen an increase in the number of working women, dual earner and single parent families, increased responsibility of adults and changing demography. Employees have seen downsizing, increased job security, increased time at work place etc. Technological changes have blurred the boundary between work and family life which have contributed to increased work life conflict.

\section{- Women in work force and changing family pattern}

There is a growing involvement of women in the labor force and hence the concomitant shift towards dual income family. The population of women in work place in 1981 was 19.67 percent and it rose to 22.73 percent in 1991 and 25.68 per cent in 2001, according to the registrar General in India.

\section{- Population Ageing}

As the population becomes more ethically diverse, it is also ageing; putting as yet unfathomed stress on businesses. An AARP survey showed that 80 per cant of baby boomers plan to work at least part time after they retire. ${ }^{3}($ Chuvala,2002)

\section{- Downsizing, Restructuring and Declines in Job Security}

Last decade has been the era of management strategy where the focus has been on cost cutting rather than people development. The changes in the economy world over and the need to compete globally led many organizations to reduce staff, restructure and outsource in order to lower the operating costs. Other companies engaged in boom and best cycles(i.e. periods of growth alternating with periods of considerable restructuring and downsizing)as products and compilation changed. For employees, this downsizing and restructuring meant that they had to deal with several issues ${ }^{8}$ (Lowe, 2000) like

1. A reshaping of the work force (more women, more diversity, ageing force)

2. Recession followed by a 'jobless recovery'

3. A diminished society safety net and greater cut backs

\section{- Technological Change}

Technological advances have fundamentally changed the nature of work. They have changed when and where one work, blurred the boundaries between work and non work, increased the place of work and changed service delivery.

- It has led to decrease in the job security and/or increase in unemployment/underemployment for those with out the skills to compete in today's labor market.

- It has led to a blurring of the boundaries between work and life as it becomes increasingly easy to work any time and anywhere.

- The use of office technology such as e mail and fax is associated with increased work goals greater job stress. 
At a time when technology was supposed to be reducing the work week and fixing up leisure time, a large segment of employees are actually working long hours.

\section{- Corporate Inertia}

Tough competition and the fast changing dynamic environment have tended to change the management tactics of yester years of: 'putting people first', 'human capital' and 'competitive advantage through people'. Employees are stretching themselves to a dangerous level of stress. Recession 2009 has further added to the imbalance. Indians working beyond the scheduled office hours has become a trend. Despite emphasizes laid on the importance of human resource, the idea that employees are the key to achieving all business goals remains a very hard sell. Organizational inertia, therefore, may have exacerbated work life balance issues for many workers, who for the most important part, have been left on their own to cope with the new relatives of the work place.

\section{Work-life balance programs in vogue}

$>$ Telecommuting: Telecommuting is a relatively new concept brought about by the widespread availability of computers and the internet. This primarily allows workers in white collar jobs to work from home by linking employees to a company's network and completing work from home. One of the primary purposes of telecommuting is to allow employees to spend less time commuting, as well as allowing their schedule to be a bit more flexible. Currently 30 percent of U.S. firms allow some form of telecommuting.(ibid)

$>$ Job-sharing - Job sharing is a voluntary arrangement of one full time position in such an arrangement that the individuals carry out all the duties of the job, simply picking up the work where other one is left. In a divided responsibility arrangement, the duties of the position is divided between the two, each being able to provide cover for the other where necessary. The split may be morning or afternoon, weekly, mid-week, a week on, a week off, etc.

$>$ Part time working: Part time working is a system whereby the employee is contracted to work fewer than the standard number of contractual hours per day.

$>$ Flex-time/Staggered Working Hours: Staggered Working Hours allow for the start and finish times than the normal business hours. The number of hours remains the same but can be staggered during the day: one can come late and go late in the evening or can work for certain hours in a staggered manner.

> Annualized hours: Annualized hour's system whereby the employees contractual working hours are expressed as the total number of hours to be worked over the year allowing flexible work patterns to be worked through out this period.

$>$ Compressed Hours: Compressed working hours permit the employees to work their total number of contractual hours to complete the assignment. Contractual hours are compressed over fewer working days. Either 5 days a week is compressed to 4 days or a fortnight into 9 days or so on.

$>$ Term Time Working: Term Time Working is a system whereby the employe4es work under the contract but can take unpaid leave of absence to fulfill personal commitment.

$>$ Voluntary Reduced Working Time: This is a system whereby it is agreed that the employee will work reduced hours for a certain period of time, with a return to full time hours at the end of this period. Generally the benefits (salary,holidays,etc.) are prorated during this time.

$>$ Occasionally working at home: This is a system whereby employee caries out a portion of their duties at home. It includes work that can be done effectively from a remote location, or is a specific task that requires high level of concentration or minimum interruption.

> Career Breaks: Career breaks allow an employee an extended period of time away from paid work, where possible with a return to the same or similar job at the end of the time.

> Leaves: Certain leaves under the legislation and provision of other leaves like flexi time leave, adoption leave, time off for health appointments, special leaves, etc help an employee in addressing and fulfilling their personal commitment.

$>$ Child and Elder care

$>$ Employee Assistance Programs

$>$ In-house store/services

$>$ Gym subsidies

$>$ Concierge services

$>$ Vacation

In addition to the work-life balance programs listed above, primarily due to the internet boom in the mid-90s and the growth in the economy, more companies offered other "perks" as well. Items such as company cars and a set number of free flights per year were normal for many companies. A four-day work-week as well as flexible hours and casual dress were common also. These perks were primarily instituted to attract, motivate 
and retain a superior quality workforce. According to a position paper published by Caux Round Table and written by David Rodbourne in 1996, "While many leading U.S. companies have extensive work-life programs, policies and practices, most have not yet changed their organizational cultures to support employees and managers who want to use work-life options."( David Rodbourne) ${ }^{4}$. This philosophy appeared to be widespread in the 1990's, because work-life programs were in place, however if an employee wanted to be a manager, they were not allowed to work four day weeks. In light of the recent economic conditions, there has been a dramatic change in how corporations view work-life balance programs. Corporations are much more cost conscious about these programs, but still realize their importance. Despite this more critical view about work-life programs, according to Jim Bird, benefits such as "Employee Assistance Programs are considered as a standard offering. I do not see them going away." In the heart of the Internet bubble, work-life balance programs were an added bonus to attract and retain quality employees.

Today, the work-life benefits have switched from company cars, significant bonuses, and other perks to employee fitness centers and dry-cleaning services. Now work-life balance programs are in place as "Recession Perks". Many corporations can no longer afford the monetary compensation they were handing out in the 1990 's. But with layoffs commonplace, these companies are looking to use their inexpensive "Recession Perks" as tools to build loyalty and encourage teamwork and camaraderie with coworkers. Through these benefits, along with the traditional programs such as insurance and retirement plans, managing the remaining workforce after layoffs is vital. When the struggling economy turns around, the remaining employees will be responsible for bringing their respective companies "back to life", and back to a competitive force.

\section{The two legs of the work-life strategy}

Until recently, most organizations have taken a one-sided "systems" approach to their work-life efforts. Their focus has been on adopting organization policies, benefits, and procedures to solve the work-life-balance problem. Although helpful, the systems approach overlooks a critical fact: At its core, work-life balance is more an individual issue that affects the organization than it is an organizational issue that affects the individual.

The systems approach asks, "What can the organization do to create a better work-life balance for the individual?" The other half of the work-life strategy, the "individual" approach, asks, "What can individual employees and managers do for themselves to create their own best work-life balance?"

\section{* The Left Leg of Work-Life Strategy-Systems approach}

The systems approach is the left leg of the ladder.

Ten options for the effective functioning of the systems leg of work-life strategy.

1. Reinforce through better communications

2. Abolish internal Friday-afternoon meetings.

3. Give a half day off on Fridays if the individual has put in the incremental hours earlier in the week and assuming that no outside customer meetings are scheduled.

4. Endorse working from home one day per week.

5. Offer subsidies for off-site exercise.

6. Create and support athletic teams.

7. Provide one or two days off with pay for approved community involvement.

8. Create and encourage an annual or quarterly "bring your family to work" day.

9. Establish a "disconnect from work" vacation policy--no cell phones or laptops.

10. Create a more accommodating "on- and off-ramp" policy for those who leave the firm.

\section{* The Right Leg of Work-Life Strategy-Individual Differences}

The right leg is essential because the best work-life balance is different for everyone. For some, working long hours creates value and balance in their lives. For others, it is not a routine they can productively or enjoyably maintain. In addition, the best work-life balance changes for each individual over time. A good work-life balance for someone starting his or her career is different from that for someone getting ready to retire. A good work-life balance for someone who is single with no children is different from that for a single parent with two children.

\section{* Dual-purpose work and life training}

Dual-purpose learning is education that applies both to learners' on-the-job lives and to their off-thejob lives. It has proven to be the quickest way to accomplish the organization's most critical work objectives and the individual's work-life balance objectives simultaneously. It is used in recruiting and for driving productivity. Because of this multifaceted HR and productivity training impact, senior executives at every level have initiated enterprise-wide work-life programs. Human resource managers who implement successful work-life training programs throughout their management ranks accomplish two major bottom-line goals. First, they increase the 
retention, commitment, and productivity of the firm's most valuable people asset, its managers and supervisors. Second, the managers and supervisors reflect a new tool set and language that produce a much more positive view of the organization at all levels. This more positive view has a cascading impact on the attitude, morale, productivity, and customer-service levels of all employees.

\section{Implementing Dual-Purpose Training}

1. Search out and evaluate the training alternatives. They include:

$\checkmark$ Internal development and delivery of a work-life training program.

$\checkmark \quad$ Outsource the training to a proven vendor.

$\checkmark$ Trainer certification: external content, internal delivery.

2. Make sure the training planned is "dual purpose" and practical. The skills that training program teaches must affect job performance and off-the job value and balance. The learning should focus on practical tools that produce immediate results during the training, both personal and professional.

3. Run a dual-purpose training pilot. Select attendees from different areas of the company, address their needs and build a success story that makes the business and budget case for a larger rollout.

4. Secure senior management's full buy-in and support. Expose senior management to the training early and get their endorsement and support.

5. Select and train the trainer(s) to do the rollout. HR professionals, trainers, members of the work-life team, and interested line managers and executives can all be good choices for trainer certification.

6. Start the training rollout with managers. Bosses are the number-one reason people quit, and the top complaints about bosses are work-life issues. Improving supervisors' and managers' skill sets has the widest and fastest impact.

7. Cascade to employees in a time frame that works for your trainers and budget resources. By delivering the same skill set to employees that you delivered to managers, you create a common tool set and work-life language to get things done more effectively on the job and create more individual value and balance off the job.

8. Put out a monthly work-life newsletter. A monthly newsletter demonstrates more than a one-time commitment to work-life balance within the organization. If the newsletter is done internally, each month interview an individual within your organization who is respected for his or her productivity and also reflects a positive balance.

9. Use multiple delivery venues. Doing so creates and reinforces the common language. Most important, it drives an ongoing positive perception about the organization's commitment to work-life balance. Work-life firms have existing packages to support the efforts. Run multiple delivery venues internally or externally with very limited administrative time or costs like:
a. Live delivery
b. On - demand Web training
c. Access to Web training for family members
d. Monthly newsletter
e. E-mail prompts

Work-Life education replaces separate work- training and life-benefit efforts with one approach that delivers key elements of both. The result is that both the work training and the life benefit are implemented more effectively and for a fraction of the costs, greatly expanding the impact of training and benefits budgets. Work-life training is the right leg--the individual side of work-life strategy ladder. It puts the responsibility and skill set in the hands of each individual to create his or her own best work-life balance.

\section{Future of work-life balance}

For true work-life balance to occur, employees need to be responsible for adopting certain behaviors which help them balance work and the other parts of their life (e.g. family, friends and self). Companies with a long-term strategy on work-life balance will recognize this and provide employees with training which addresses personal shortfalls they might have that keep them from achieving work-life balance. Even if companies implement programs to address the personal shortfalls of employees, the achievement of long-term work-life balance is still a dream unaccomplished. Changing the habits of employees does not necessarily imply a change in "work-life balance" particularly if the culture of the work environment does not change. When both company plans and employee efforts are complimentary, true work-life balance can be achieved.

\section{Conclusion}

The "right" work-life programs definitely offer a competitive advantage in recruiting, retention, productivity and customer service levels - and as a result profitability. Work-life balance programs are definitely competitive advantage but not to the exclusion of social responsibility. 


\section{References}

[1] Bond,S., 'Organizational culture and work-life conflict in the UK', International Journal Of Sociology and Social Policy, vol.24(12),2004,pp.1-23.

[2] Chhabra,T.N., Principles and Practice of Management, Dhanpat Rai \& Co., 2000, p.583.

[3] Chuvala, Bob, 'Demographic changes creating diverse,aging force', Fairfeild Country Business Journal, August 2002.

[4] David Rodbourne, "Learning as We Go, Work-Life Policies \& Practices for Business", July 1996.

[5] EEO Trust 2006, Work life Survey, Auckland, http://www.eeotrust.org.nz/awardsleaders.cfm?content_id=793,accessed on 16 th March,2010). Publiched date 30 mar 2014

[6] Gionfriddo J and Dhingra L,: 'Retaining high Tech Talent', Compensation and Benefits Review, Sep-Oct,1999,pp.31-35.

[7] Hudson, 'The Case for Work-Life Balance: closing the gap between Policy and Practice', Hudson: Australia and New zealand, 2005, http://au.hudson.com/documents/emp_au_Hudson_Work- ife_A4_Std.pdf(assessed on 16.10.2010).

[8] Lowe, The quality of Work: A People Centered Agenda, Toronto: Oxford University Press,2000.

[9] Vanderkolk and Young,The work and the family Revolutuin: How Conmpanies can keep employees happy and business profitable, New York: Facts on File, Inc.,1991. 